\title{
Cytological Studies on Some Kashmir Grasses \\ VI. Cytomorphological polymorphism in Alopecurus aequalis Sobol.
}

\author{
Kuldeep Kumar Koul ${ }^{1}$ and R. N. Gohil \\ Cytogenetics Laboratory, Department of Botany, University of Kashmir, \\ Srinagar-190 006, India
}

Accepted November 10, 1989

Observations made on cytology of Alopecurus aequalis, a temperate species, by workers like Katterman (1930), Johnsson (1941), Ono and Tateoka (1953), Hubbard (1954), Löve and Löve (1956), Bowden (1960), Chen and Hsu (1962), Mehra and Remanandan (1973) and Sieber and Murray (1981) revealed a single chromosome number $(2 n=2 x=14)$ for this species. Presently, in addition to the diploid, a tetraploid cytotype $(2 n=4 x=28)$ of this species has been isolated from Ganderbal area in Kashmir. The present communication puts on record the morphological details of the two cytotypes studied and also the salient features regarding the somatic chromosomes and behaviour of chromosomes during reduction division.

\section{Materials and methods}

Detailed studies have been carried out in two populations of this species $i . e$., Tangmarg $(2,150 \mathrm{~m})$ and Ganderbal $(1,650 \mathrm{~m})$. Morphological parameters of the two cytotypes were studied both in the field as well as from pressed specimens. Somatic chromosomes were studied from actively dividing nucellar cells. For this ovaries of suitable sizes, excised from the inflorescences, were pretreated with $0.4 \%$ colchicine for $4-5 \mathrm{hrs}$. These were then washed thoroughly with tap water, transferred to $1: 3$ acetic alcohol for $24 \mathrm{hrs}$, and stored in $70 \%$ ethyl alcohol at temperature below $10^{\circ} \mathrm{C}$. Before making squash preparations the ovaries were hydrolyzed in $1 \mathrm{~N} \mathrm{HCl}$ for 10-15 minutes and then stained in leucobasic fuchsin. After this ovules were dissected out of ovaries and squashed in $1 \%$ aceto carmine. Chromosomes have been classified following Levan et al. (1964).

To study the meiotic behaviour of chromosomes the methods used are the same as mentioned earlier (Gohil and Koul 1988).

\section{Observations}

Morphology In the two populations studied presently significant differences were observed in different morphological parameters (Table 1, Fig. 1).

Karyotype Study of the well spread metaphase plates revealed 14 and 28 chromosomes in the cells of Tangmarg and Ganderbal populations respectively (Figs. 2, 3). Chromosomes in both these cytotypes, following the classification of Levan et al. (1964), were of 3 types i.e. chromosomes with centromere in median point ( $\mathrm{M} ; \mathrm{r}$ value 1 ), median region ( $\mathrm{m} ; \mathrm{r}$ value $1-1.7$ ) and sub median region ( $\mathrm{Sm} ; \mathrm{r}$ value 1.7-3). Salient features of these karyotypes are given in Table 2 .

Present address: Cytogenetics Laboratory, Department of Botany, University of Delhi, Delhi-110007, India. 
While all the 14 chromosomes of Tangmarg population can be arranged in 7 homomorphic pairs, the 28 chromosomes of Ganderbal population exhibit two types of homomorphic groupings $i$.e 10 groups of 2 chromosomes each and 2 groups of 4 chromosomes each (Figs. 4,5 ). In none of these populations could a satellited or a secondarily constricted chromosome be distinguished.

Microsporogenesis The pollen mother cell meiosis in the plants of Tangmarg population was normal with seven bivalents discernible in all the cells studied at diakinesis and metaphaseI (Figs. 6, 7). The mean chiasmata frequency per cell and per bivalent at diakinesis was $11.16 \pm 0.37$ and 1.98 and in cells at metaphase-I it was $9.66 \pm 0.74$ and 1.39 per cell and per bivalent respectively. In cells at anaphase-I, normal segregation of $7: 7$ chromosomes was observed (Fig. 8) and the pollen stainability in the plants of this population was $98 \%$. In the plants of Ganderbal population $(n=14)$ multivalent associations, besides bivalents and univalents, were discernible in cells at diplotene and metaphase-I (Figs. 9, 10, 11). Table 3 sums up the frequency of cells with different chromosomal association at each stage.

Table 1. Morphological differences observed in the two populations of A. aequalis

\begin{tabular}{|c|c|c|}
\hline \multirow{2}{*}{ Characters } & \multicolumn{2}{|c|}{ Populations } \\
\hline & Tangmarg $(2,150 \mathrm{~m})$ & Ganderbal $(1,650 \mathrm{~m})$ \\
\hline Habitat & Hydrophyte & Mesophyte \\
\hline Plant height & $35-45 \mathrm{~cm}$ & $22.6-26.3 \mathrm{~cm}$ \\
\hline Internode length & $4.5-6.5 \mathrm{~cm}$ & $4.4-8.1 \mathrm{~cm}$ \\
\hline Number of internodes & 6 & $2-3$ \\
\hline \multicolumn{3}{|l|}{ Leaf } \\
\hline Sheath length & $3.1-5.2 \mathrm{~cm}$ & $2.3-5.6 \mathrm{~cm}$ \\
\hline Lamina length & $4.3-8.5 \mathrm{~cm}$ & $2.1-5.1 \mathrm{~cm}$ \\
\hline Inflorescence length & $3.7-5.1 \mathrm{~cm}$ & $3.5-4.8 \mathrm{~cm}$ \\
\hline \multicolumn{3}{|l|}{ Flower Shape } \\
\hline Glumes & Broad & Narrow \\
\hline Awns & Long & Short \\
\hline \multicolumn{3}{|l|}{ Pollen } \\
\hline Stainability & $98 \%$ & $97 \%$ \\
\hline Size & $21 \mu \mathrm{m}$ & $30 \mu \mathrm{m}$ \\
\hline
\end{tabular}

As is evident from Table 3 while a maximum of three quadrivalents were observed in $3.03 \%$ PMCs studied at diplotene (Fig. 9), at metaphase-I a maximum of 2 quadrivalents (Fig. 11) were observed in $9.68 \%$ cells. The chiasmata frequency determined per cell and per bivalent at diplotene was found to be $28.9 \pm 1.01$ and 2.06 and in cells at metaphase-I it was $23.66 \pm 0.66$ and 1.68. The chromosomal disjunction in cells at anaphase-I, despite the presence of multivalent associations at metaphase-I, was normal with 14 chromosomes going to each pole (Fig. 13). However, in a single cell irregular disjunction of 12:16 chromosomes was observed (Fig. 12). 97\% pollen produced by this population stained positively with aceto carmine.

\section{Discussion}

Members of the genus Alopecurus, represented by 50 species in the temperate region (Cope 1982), provide excellent fodder for the live stock. Cytologically about 36 species have been worked out (Fedorov 1969, Mehra and Sunder 1970, Mehra and Remanandan 1973 and Sieber and Murray 1981). The chromosome numbers in these species, based on $x=7$ (Darlington 
and Wylie 1955), range from $2 n=14$ to 130 reported in A. alpinus (Flovik 1940) which work out to be approximately 18 ploid. Interestingly, despite the presence of such a high ploidy level (18 ploid) in this genus, for some of the taxa, including $A$. aequalis, only diploids $(2 n=14)$ are reported (Fedorov 1969 and Sieber and Murray 1981), indicating thereby that in these species

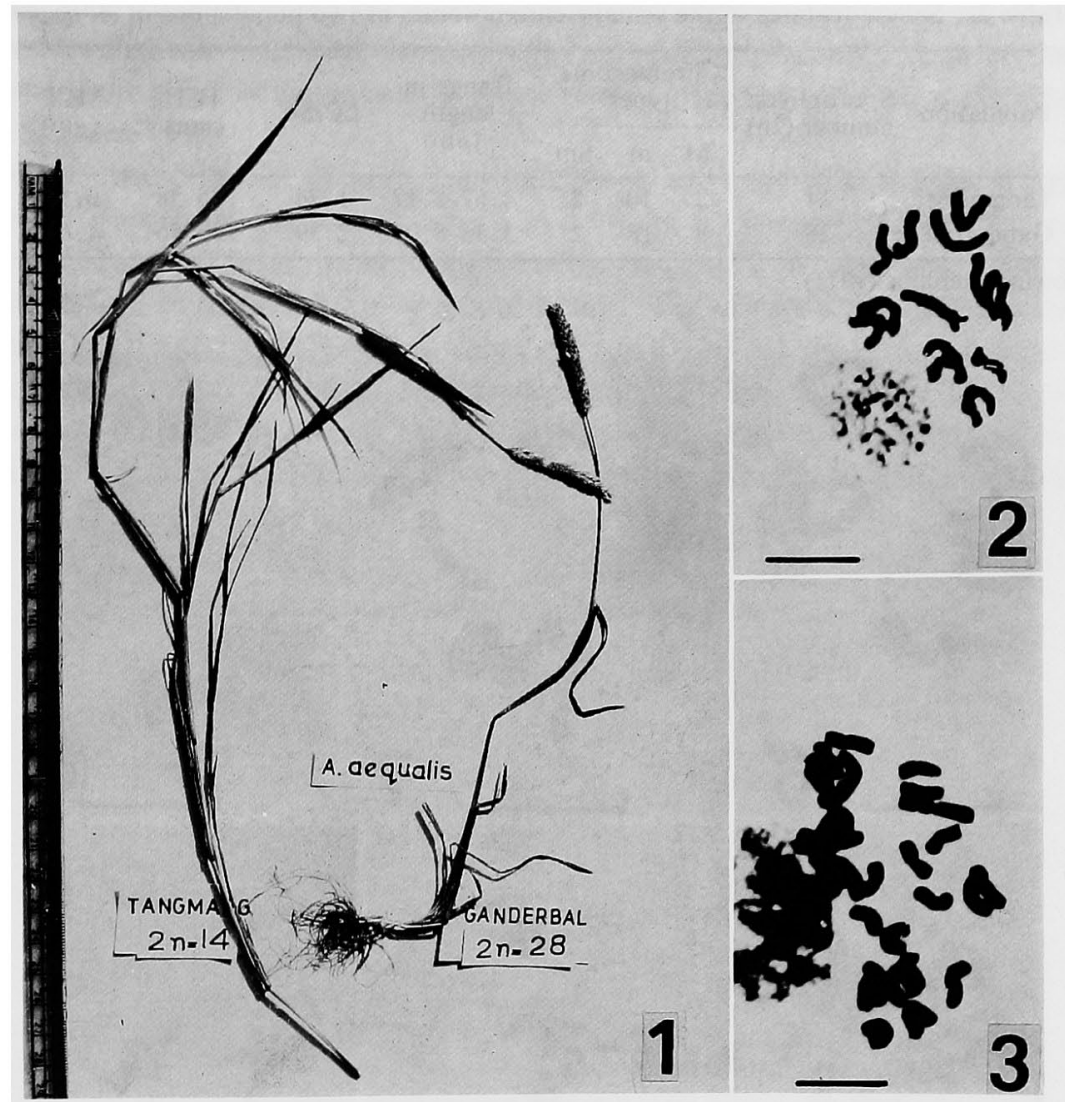

IHillith
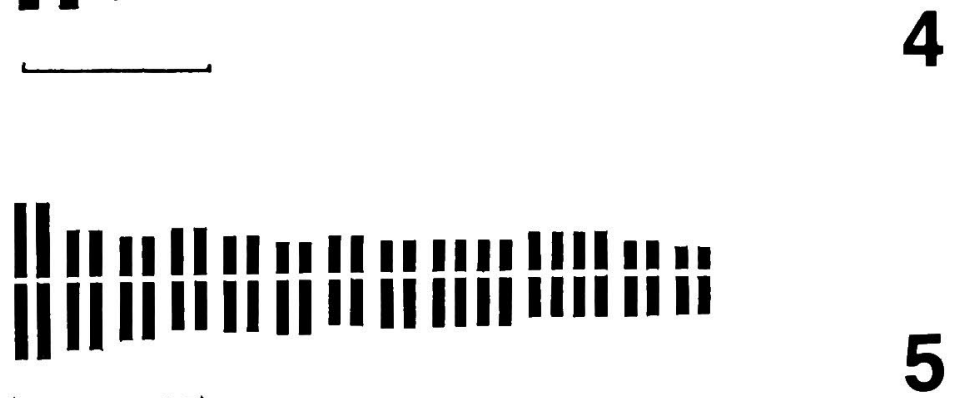

Figs. 1-5. 1, Morphological variability observed in two populations of $A$. aequalis. 2, somatic chromosomes of diploid $(2 n=14) . \quad 3$, tetraploid $(2 n=28)$ A. aequalis. 4 and 5 , idiogram of the somatic chromosomes of diploid (4) and tetraploid (5) populations respectively. Scale $=10 \mu \mathrm{m}$. 
polyploidy has not played any significant role in evolution. This perhaps could be due to the failure of the species to tolerate drastic numerical changes in chromosomes. Presently, in addition to a diploid cytotype with $2 n=14$ (Tangmarg population) which is in conformity with the earlier records, a new cytotype with $2 n=28$ has been isolated from Ganderbal region.

Table 2. Salient features of the somatic chromosomes of two populations of $A$. aequalis

\begin{tabular}{|c|c|c|c|c|c|c|c|c|c|c|}
\hline \multirow{2}{*}{ S. No. } & \multirow{2}{*}{ Population } & \multirow{2}{*}{$\begin{array}{l}\text { Sporophytic } \\
\text { number }(2 n)\end{array}$} & \multicolumn{3}{|c|}{$\begin{array}{c}\text { Chromosome } \\
\text { types }\end{array}$} & \multirow{2}{*}{$\begin{array}{c}\text { Range in } \\
\text { length } \\
(\mu \mathrm{m})\end{array}$} & \multirow{2}{*}{$\mathrm{LC} / \mathrm{SC}$} & \multirow{2}{*}{$\begin{array}{l}\text { TCL } \\
(\mu \mathrm{m})\end{array}$} & \multirow{2}{*}{$\begin{array}{l}\text { MCL } \\
(\mu \mathrm{m})\end{array}$} & \multirow{2}{*}{$\begin{array}{l}\text { Symmetry* } \\
\text { class }\end{array}$} \\
\hline & & & $\mathbf{M}$ & $\mathrm{m}$ & $\mathrm{Sm}$ & & & & & \\
\hline 1. & Tangmarg & 14 & 2 & 10 & 2 & $4.67-8.17$ & 1.74 & 85.58 & 6.11 & $3 \mathrm{~A}$ \\
\hline 2. & Ganderbal & 28 & 8 & 18 & 2 & $3.36-8.04$ & 2.39 & 130.76 & 4.67 & 4B \\
\hline
\end{tabular}

* Following Stebbins (1971).

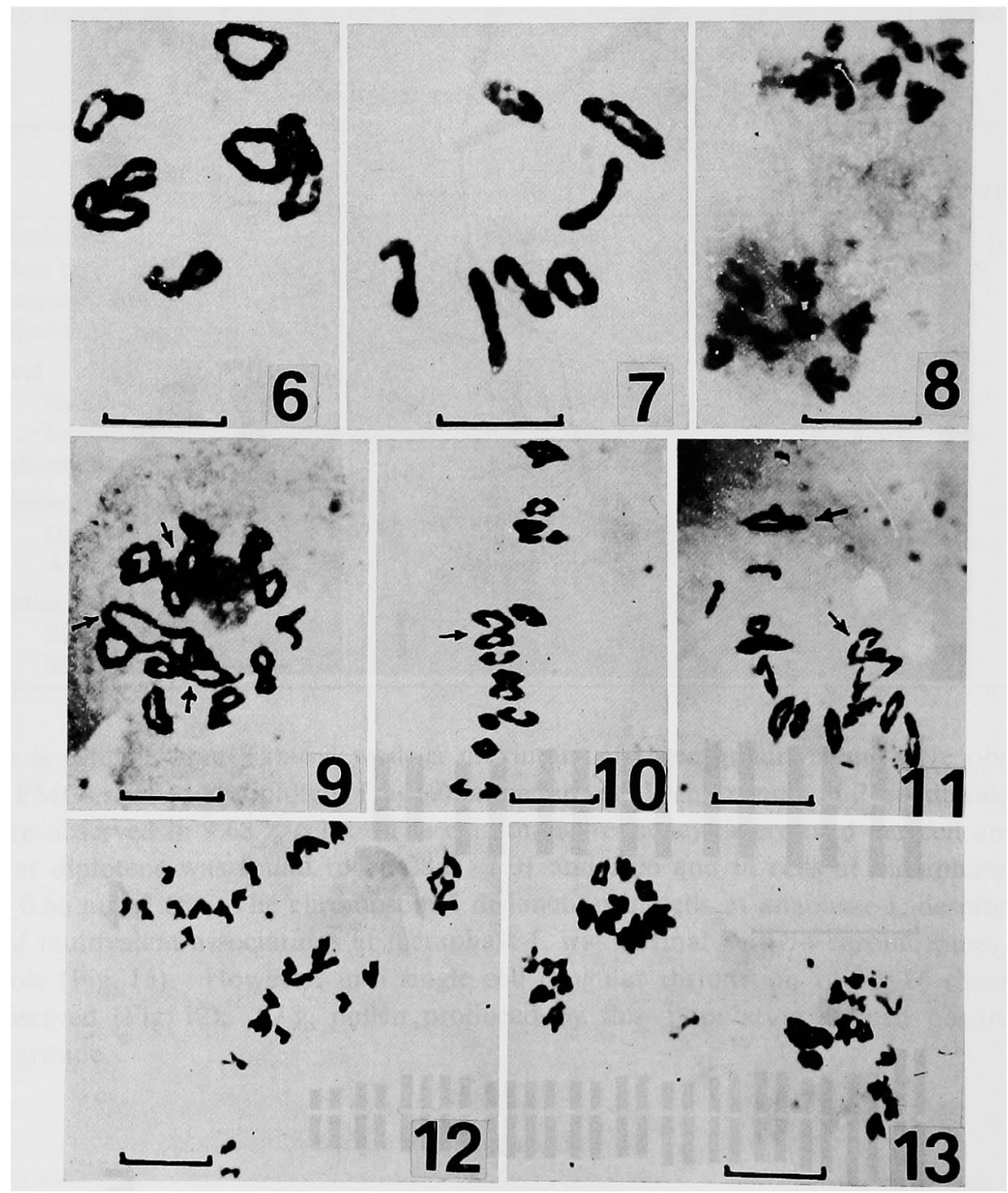

Figs. 6-13. Microsporogenesis in two populations of A. aequalis. 6, a cell at diakinesis with 7 IIs. 7, metaphase-I with 7 IIs. 8, anaphase-I showing normal segregation of 7: 7 chromosomes. 9, a cell at diplotene with 3 IV +8 II (multivalents at arrows). 10 and 11, cells at metaphase-I with 1 and 2 quadrivalents (arrows) respectively. 12, anaphase-I showing segregation of 12 : 16 chromosomes. 13 , anaphase-I with normal segregation of $14: 14$. Scale $=10 \mu \mathrm{m}$. 
Since for this genus base number $x=7$ is suggested, it is likely that the Ganderbal population is a tetraploid being reported for the first time in this species. A critical scrutiny of the Table 1 clearly reveals that in all the morphological parameters like plant height, inflorescence length etc. the diploid individuals of Tangmarg population are more sturdy than their tetraploid counterpart. Although the morphological difference observed can be due to differences in their habitats, such changes being the result of different chromosome numbers $(2 n=14,28)$ can also not be ruled out. In case the variability is because of genetic reasons then it is a case of reverse gigas effect of polyploidy a phenomenon already known in some other plants (Mehra and Sharma 1975).

The somatic chromosomes of both the populations are large with the size ranging from 4.67-8.17 $\mu \mathrm{m}$ in Tangmarg population and 3.36-8.04 $\mu \mathrm{m}$ in Ganderbal population. While the somatic chromosome complement of diploid comprises of $2 \mathrm{M}, 10 \mathrm{~m}$ and $2 \mathrm{Sm}$, the complement of tetraploid consists of $8 \mathrm{M}, 18 \mathrm{~m}$ and $2 \mathrm{Sm}$. The chromosomes of both these populations form a graded series without any sharp difference between the largest and the smallest chromosome. Nevertheless, a slight decrease in over all chromosome length accompanied by increase in chromosome number is clearly visible. The total chromatin length in keeping with the increased ploidy level in Ganderbal population is higher. The other interesting

Table 3. Chromosomal configurations observed at diplotene and metaphase-I in Ganderbal population of $A$. aequalis

\begin{tabular}{cc}
\hline \hline Chromosomal associations & Percent cells \\
\hline Diplotene & 3.03 \\
3 IV +8 II & 21.21 \\
2 IV+10 II & 72.72 \\
1 IV +12 II & 3.03 \\
1 IV+11 II +2 I & \\
Metaphase-I & 3.23 \\
2 IV +10 II & 6.45 \\
2 IV+9 II +2 I & 80.64 \\
1 IV +12 II & 9.67 \\
14 II &
\end{tabular}

feature observed is the higher LC/SC ratio in Ganderbal population which point towards its advanced nature. This view is further substantiated by the fact that while the tetraploid population belongs to $4 \mathrm{~B}$ symmetry class, the diploid can be placed in $3 \mathrm{~A}$ symmetry class of Stebbins (1971). The absence of NORs in the present material can be ascribed to the fact that either these regions are not clearly differentiated or have escaped notice. However, here it may be mentioned that sometimes NOR lies very close to the centromere and as such it is difficult of differentiate the two. According to Kurita $(1960,1968)$, the function of NORs in such cases is taken over by the elongated centromere formed probably by the fusion of centromere and the secondarily constricted region.

The 28 chromosomes of the tetraploid cytotype formed 2 types of groups $i . e .10$ groups with 2 chromosomes each and 2 with 4 each (Fig. 5). Presence of two quadruplets in its idiogram indicates that the present population is a segmental allotetraploid with little homology between 4 of its constituent genomes, the presence of upto 3 quadrivalents in $3.03 \%$ cells at diplotene and 2 quadrivalents only in $9.68 \%$ cells at metaphase-I support this view. Despite the presence of quadrivalents at metaphase-I, the anaphase-I proceeds regularly with perfect segregation of 14: 14 chromosomes leading to $97 \%$ pollen stainability. Although the gametic lethality in any organism depends on the genic combination it carries, in the population under 
reference the high pollen stainability can be explained either on the basis of selective segregation of multivalents which depends on the orientation of multivalents or else it is due to its polyploid nature. According to Schulz-Schaeffer (1980) there are 4 possible ways in which multivalents orient at metaphase plate; two alternate orientations (alt. 1 and alt. 2) and two adjacent orientations (adj. 1 and adj. 2). While the alternate orientation facilitates the movement of homologous centromeres to opposite poles resulting in the formation of viable gametes with balanced chromosome complements, in the adjacent types gametes with duplicated and deleted chromosome complements are formed. In present material, the high pollen viability preceeded by multivalent association at metaphase-I must have been the result of alternate type of orientations. Similar type of situation has been observed by Gohil and Raina (1987) in Hesperis matronalis.

The perusal of available literature reveals that of the total of 5 species of Alopecurus reported from Kashmir (Stewart 1972), cytology of 4 namely $A$. aequalis $(2 \mathrm{n}=2 \mathrm{x}=14), A$. arundinaceus $(2 \mathrm{n}=4 \mathrm{x}=28)$, A. myosuroides $(2 \mathrm{n}=4 \mathrm{x}=28)$ and $A$. himalaicus $(2 \mathrm{n}=6 \mathrm{x}+3=45)$ have been worked out (Mehra and Sunder 1970 and Mehra and Remanandan 1973). Mehra and Remanandan (1973) had reported translocations in the Tangmarg collection of $A$. aequalis which, however, could not be confirmed presently. The review of available literature also reveals that so far no attempt has been made to study the somatic chromosomes of this species and, therefore, it is not possible to compare the present populations with others.

\section{Summary}

Detailed cytology of two populations of Alopecurus aequalis has been worked out. While the count of $2 n=14$ observed in Tangmarg population confirms the earlier reports, the $2 n=28$ in the Ganderbal population is a new record. In the present paper morphological and cytological details of the two cytotypes are described.

\section{Acknowledgements}

We would like to express our deep appreciation to the Director, Royal Botanic Gardens, Kew, U. K. for confirming our identification. The financial support provided by University Grants Commission, New Delhi, India, is also thankfully acknowledged.

\section{References}

Bowden, W. M. 1960. Chromosome numbers and taxonomic notes on northern grasses III. Twenty five genera. Canadian Jour. Bot. 38: 541-557.

Chen, C. C. and Hsu, C. C. 1962. Cytological studies on Taiwan grasses (2). Chromosome numbers of some miscellaneous tribes. Jour. Japanese Bot. 37: 300-313.

Cope, T. A. 1982. Poaceae. In: E. Nasir and S. I. Ali (ed), Flora of Pakistan No. 143. Karachi University Press, Karachi.

Darlington, C. D. and Wylie, A. P. 1955. Chromosome Atlas of Flowering Plants. pp. 390. George Allen and Unwin Ltd., London.

Fedorov, An. A. 1969. Chromosome Numbers of Flowering Plants. Otto Koeltz Science Publishers, West Germany.

Flovik, K. 1940. Chromosome numbers and polyploidy within the flora of Spitzbergen. Hereditas 26: 430440.

Gohil, R. N. and Koul, K. K. 1988. Reduction division in the hexaploid Agrostis filipes Hook. f. Cytologia 53: $287-290$.

- and Raina, R. 1987. Polyploidy accompanied by structural alterations in the evolution of Hesperis matronalis L. Cytologia 52: 223-228. 
Hubbard, C. E. 1954. Grasses. A guide to their structure, identification, uses, and distribution in the British Isles. Hardmondsworth, Middlesex, Penguin Books Ltd.: 1-428.

Johnsson, H. 1941. Cytological studies in the genus Alopecurus. Acta. Univ. Lundensis, Avd. 2, 37 : 1-43. Katterman, G. 1930. Chromosomenuntersuchungen bei Gramineen. Planta 12: 19-37.

Kurita, M. 1960. Nucleolar chromosome with long centromere. Rep. Biol. Inst. Ehime Univ. 9: 1-8. - 1968. Chromosome study in seven Allium species. Mem. Ehime Univ. Sect. II, Ser. B 6: 1-9.

Levan, A., Fredger, K. and Sandberg, A. A. 1964. Nomenclature for centromere position on chromosomes. Hereditas 52: 201-220.

Löve, A. and Löve, D. 1956. Cytotaxonomical conspectus of the Icelandica flora. Acta Horti Gothoburgensis 20: $65-291$.

Mehra, P. N. and Remanandan, P. 1973. Cytological investigation on W. Himalayan Poaeoideae. Cytologia 38: $237-258$.

- and Sharma, M. L. 1975. Cytological studies in some Central and Eastern Himalayan grasses III. The Agrostideae, Aveneae, Brachypodieae, Bromeae, Festudeac, Phalarideae and Triticeae. Cytologia 40: $441-452$.

- and Sunder, S. 1970. Cytological studies in the North-Indian grasses (Part II). Res. Bull. Panjab. Univ. 20: 503-539.

Ono, H. and Tateoka, T. 1953. Karyotaxonomy in Poaceae I. Chromosomes and taxonomic relations in some Japanese grasses. Bot. Mag. (Tokyo) 66: 775-776.

Schulz-Schaeffer, J. 1980. Cytogenetics: Plants, Animals, Humans. Springer-Verlag, New York.

Sieber, V. K. and Murray, B. G. 1981. Structural and numerical polymorphism in natural populations of Alopecurus (Poaceae). Plant Syst. Evol, 139: 121-126.

Stebbins, G. L. 1971. Chromosomal Evolution in Higher Plants. Edward Arnold Publ., London.

Stewart, R. R. 1972. (Flora of West Pakistan) An annotated catalogue of the vascular plants of West Pakistan and Kashimir. 